\title{
STUDYING RAIN WATER CATCHMENT POTENTIALITIES IN THE NORTHWEST COAST OF EGYPT USING REMOTE SENSING AND GEOGRAPHIC INFORMATION SYSTEM
}

\author{
Asmaa A. Khater ${ }^{1 *}$, Abou-Hadid ${ }^{2}$ A.F., El-Behairy ${ }^{2}$ U.A., \\ Aboelghar ${ }^{1}$ M.A. and Ali ${ }^{1}$ A.M.
}

1- Soil and Marine Division, Agric. Application Dept., Agric., National Authority for Remote Sensing and Space Sci., Cairo, Egypt

2- Horticulture Dept., Fac. of Agric., Ain Shams Univ., P.O. Box 68, Hadayek Shobra11241, Cairo, Egypt

\section{*Corresponding author: asmaaahmed khater@yahoo.com}

\section{ABSTRACT}

Sustainable agricultural development of the desert areas of Egypt under the scarcity of irrigation water is a significant national challenge. Existing water harvesting techniques on the northwest coast of Egypt do not ensure the optimal use of rainfall for agricultural purposes. Basin-scale hydrology potentialities were studied to investigate how available annual rainfall could be used in agriculture irrigation to increase crop production.

The present study includes data related to agricultural production in the form of geospatial layers including climate, soil, land covers unite and rainwater catchment areas. Thematic classification of Sentinal-2 imagery was carried out to produce the land cover and crop maps following based on the (FAO) system of land cover classification. Contour lines and spot height points were used to create a digital elevation model (DEM). Then, DEM was used to delineate basins, sub-basins, and water outlet points using the Soil and Water Assessment Tool (Arc SWAT). Main soil mapping units of the study area identified from Land Master Plan maps it was (Very shallow gravelly and rocky soils and barren rock). Climatic data collected from the Central Laboratory for Climate. The results showed that the study area receives a significant amount of precipitation almost every three years, however, water harvesting methods are inappropriate to store water to be used in agricultural during drought seasons. The amount of precipitation(81.9 $\mathrm{mm})$, surface water runoff(4.46 $\mathrm{mm})$, potential evapotranspiration(70.5 mm), and actual evapotranspiration $(7.10 \mathrm{~mm})$ for the years (2004 to 2017) shown as results of (Arc SWAT). The land
\end{abstract}

cover map showed that tree crops (olive and fig) cover $195.8 \mathrm{~km} 2$ when herbaceous crops (barley and wheat) cover $154 \mathrm{~km} 2$. The maximum elevation was 250 meters above sea level while the lowest one was -3 meters below sea level. The study area receives a massive variable amount of precipitation; however, water harvesting methods are inappropriate to store water for purposes.

Keywords: Sentinel-2, Arc SWAT, Rainwater catchment, Water harvesting, Northwest cost

\section{INTRODUCTION}

Remote sensing technology proved to be a powerful approach to gain lower cost, temporal, and accurate information for natural resources and land surface. Agricultural applications of remote sensing and geographic information systems (GIS) could be categorized into inventorying, mapping and management. A combination of data extracted from satellite imagery with other land information in a GIS environment ensures better agricultural control. The study was carried out on the northwest coast of Egypt. This area depends on rainfall as the only source of irrigation water; however, it is problematic to depend on the direct use of rain for irrigation as rain falls only in winter is significantly different amounts across the temporal seasons. These conditions force farmers to use water harvesting systems. Some of the indigenous systems could be improved. At the same time, accumulated knowledge accompanying the new methods to collect and integrate information could maximize the use of rainwater. Many researches were carried out to study potential water harvesting in this 
area. Geographic information systems (GIS) and remote sensing (RS) have been used effectively to locate suitable water harvesting sites. (Rashash and El-Nahry, 2015) observed the optimal locations for constructing small dams as a method for water harvesting in a case study from (Fuka to Matrouh).

The current study tries to integrate many geospatial layers representing the main three factors of agricultural production (irrigation water, soil, and climate) to propose new ideas for optimal agricultural in the northwest coast of Egypt. It was necessary as the first step towards this objective to identify the present land cover and classify their units according to international standard. Therefore, the land cover identification and classification approach presented by the Food and Agriculture Organization (FAO), Water resources are under pressure due to land use practices and climate change. Land use pattern changes and their estimation describe the utilization of land resources by human activities, particularly agriculture and urbanization (Nian et al 2014). Last modified in the year 2000 (FAO-LCCS) used in the current study. This approach was proposed to introduce a land cover classification scheme that brings the land-cover community together to produce worldwide applicable land cover dataset (Ahlqvist, 2008). This system was frequently used in Egypt to create land cover maps for different areas, including the Sinai Peninsula, north, and southern Nile valley (Arafat et al 2014).

Soil and Water Assessment Tool (SWAT) used in the current study to delineate basins and subbasins and water catchment areas and then outline areas of high priorities for new water harvesting projects and sustainable agricultural development as well. This system is the most frequently applied water quality modeling system. The strength of SWAT is it uses readily available input data (Santhi et al 2001; Borah and Bera, 2004; Ramanarayanan et al 2005). It is used to observe the surface and groundwater quantity and quality. In the current study, the integration of all necessary geospatial layers that are related to the agricultural process was carried out as a complete geodatabase for the case study from Ras AlHikmah to Ras Alam Alroum. Rainwater catchment areas were delineated, and estimation of actual and potential evapotranspiration was carried out. The areas of rainwater catchment should be targeted for new water harvesting projects. These areas are considered promising for agricultural development based on a newly cropping system.
The objective of the current study is to investigate the potentialities of rainwater catchment in the study area. This will be the basis for the newly proposed cropping pattern and agricultural management plans. The objective will be achieved through the integration of all necessary geospatial layers that are related to the agricultural process in the study area Ras Al-Hikmah to Ras Alam Alroum. Rainwater catchment areas were delineated, and estimation of actual and potential evapotranspiration was carried out. The areas of rainwater catchment should be targeted for new water harvesting projects. These areas are considered promising for agricultural development based on a newly cropping system.

\section{MATERIAL AND METHOD}

\subsection{Study area}

Location of the investigated area is the northwest coast of Egypt extending from Ras Elhekmah to the east to Ras Alam Elroum in the west $\left(31^{\circ} 27^{\prime} 42.32^{\prime \prime}\right.$ to $31^{\circ} 00^{\prime} 59.80^{\prime \prime}$ North) and from

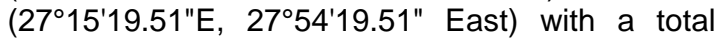
area of $2152 \mathrm{~km} 2$ (Fig. 1). Climate identified semiarid Mediterranean climate with, moderate, rainy winter. Assessment of climatic conditions showed that in December (from 2001 to 2015) the average air temperature was $16^{\circ} \mathrm{C}$, and the average rainfall is approximately $34.6 \mathrm{~mm}$. The maximum value of precipitation in a day is about $7.1 \mathrm{~mm}$. The average wind speed value was $5.15 \mathrm{~km} / \mathrm{h}$. In April, the average temperature is $20.8^{\circ} \mathrm{C}$, and the average rainfall was approximately $8.80 \mathrm{~mm}$. The maximum amount of rain in a day is about $1 \mathrm{~mm}$ when the average wind speed value is $5.63 \mathrm{~km} / \mathrm{h}$.

\subsection{Satellite image}

One Sentinel-2 satellite image was used to produce the land cover and crop map. The image was downloaded, unzipped and stacked using snap software. And then supervised classification was created. The Sentinel-2 instrument provides measurements with the following resolutions: the revisit frequency of every single satellite is ten days, and the combined constellation revisit is five days. Sentinel-2 spatial resolution is dependent on the particular spectral band. Sentinel-2 data acquired on 13 spectral bands in the visible and near-infrared spectrum (VNIR) and shortwave infrared (SWIR):four bands at $10 \mathrm{~m}: 490 \mathrm{~nm}$ (B2), $560 \mathrm{~nm}$ (B3), $665 \mathrm{~nm}$ (B4), $842 \mathrm{~nm}$ (B8) This is the set of bands that have been used, six bands at 20 m: 705 nm (B5), 740 nm (B6), 783 nm (B7), 865 $\mathrm{nm}$ (B8a), $1610 \mathrm{~nm}$ (B11), $2190 \mathrm{~nm}$ (B12) and three bands at $60 \mathrm{~m}: 443 \mathrm{~nm}$ (B1), $945 \mathrm{~nm}$ (B9) and $1375 \mathrm{~nm}$ (B10). 

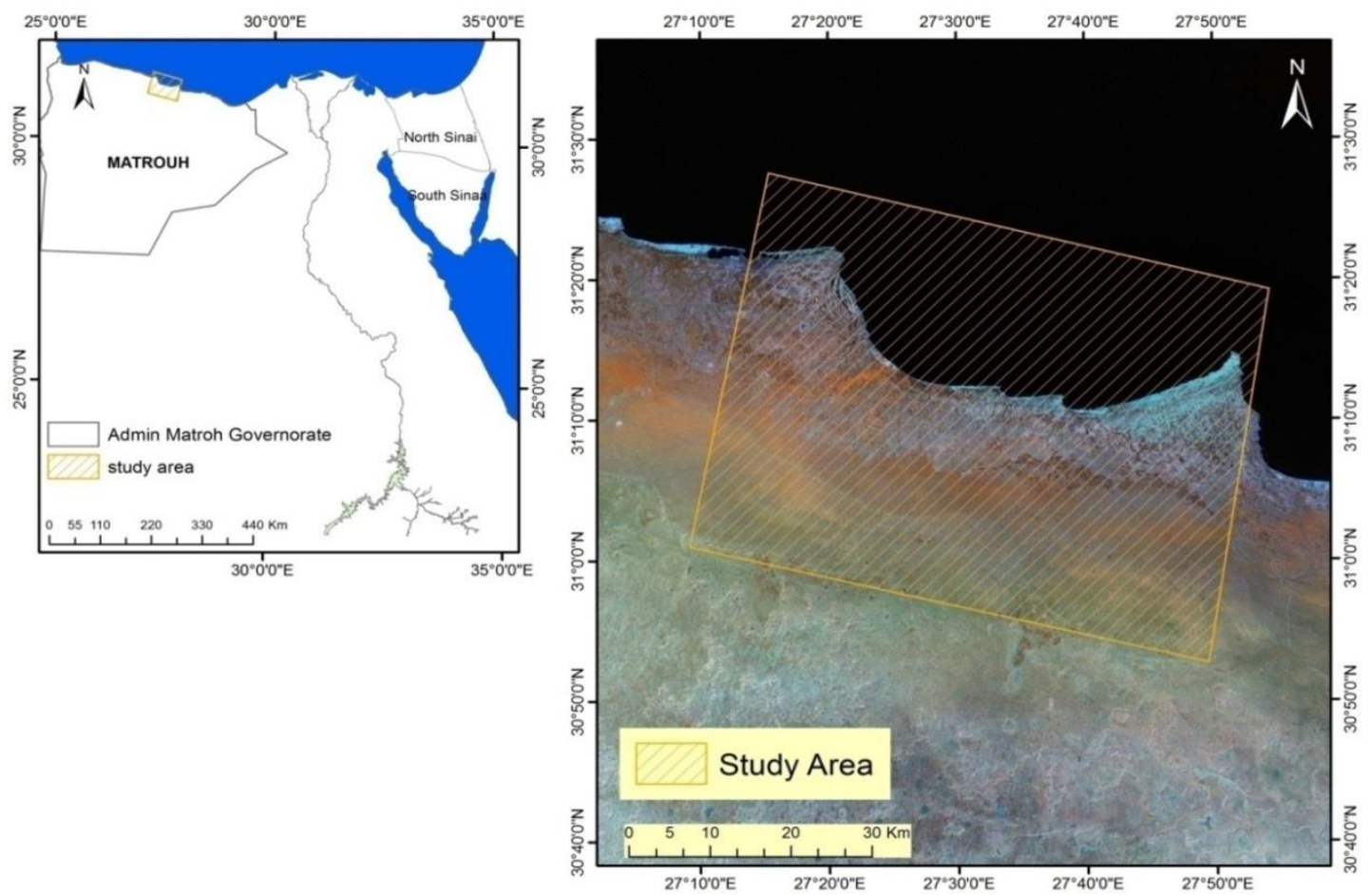

Fig. 1. The location of the study area

\subsection{FAO Land Cover Classification system (LCCS)}

Depending on the FAO LCCS system, land cover and land use maps produced. The FAO method is a "priority" classification system, which defines all the classes before the classification conducted. The advantage of this approach is the possibility to maintain the standardization of classes. For this propose, LCCS developed predefined classification criteria or classifier to identify each class, instead of identifying the class itself. LCCS system groups all land covers in eight categories and any location on the earth surface can be categorized into one of these without contradiction. The maximum likelihood classifier was used to produce land use and land cover map from Sentinal-2 data using ground control points (GCP). Water resources are under pressure due to land use practices and climate change. Land use pattern changes and their estimation describe the utilization of land resources by human activities, particularly agriculture and urbanization (Nian et al
2014). Besides, identifying and mapping crops is essential for local and national scales to forecast grain yield, collect crop production statistics, and to identify factors that influence crop stress. As observed through field investigation, tree cover includes mainly fig and olive when the dominant herbaceous crops are wheat and barley.

Kappa is a measure of agreement between two raters, each of whom independently classifies each of a sample of subjects into one of a set of mutually exclusive and exhaustive categories. ERDAS Imagine software was used to calculate error matrix and kappa statistics. The kappa computed As:

$$
k=\frac{p \sum_{i=1}^{r} x_{i i}-\sum_{i=1}^{r}\left(x_{i+} \times x_{+i}\right)}{p^{2}-\sum_{i=1}^{r}\left(x_{i+} \times x_{+i}\right)}
$$

where:

$p$ : the total number of sites in the matrix

$r$ : the number of rows in the matrix,

$X_{\text {ii: }}$ the number in row I and column

$\mathrm{I}, \mathrm{X}_{+\mathrm{i}}$ : the total for the row

I and $X_{i+}$ : the total for column $i$ 


\subsection{Land master plan map}

The land Master Plane (LMP) map at scale 1:100000 was used to determine soil units and soil types. It was used in the SWAT model. The (LMP) sheets (soil units) were geo-referenced, digitized, and reviewed. Then, all necessary information was updated and tabulated to inserted into the dataset. The LMP included land capability maps, land management categories, and soil units. The land master plan (LMP) of Egypt was issued in 1986, as a joint cooperation between the Egyptian Government represented by the Ministry of development, new communities and land reclamation; and the kingdom of the Netherlands, represented by Ministry of foreign affairs directorate general for international cooperation. Euroconsult-Pacer consultants carried out the activities, based on the results of check-surveys of the high dam soil survey (FAO, 1965), and new reconnaissance and semi-detailed soil studies performed by General Authority for Rehabilitation Projects and Agricultural Development (GARPAD) in 1985. Bahnassy et al (2007)

\section{Digital Elevation Model (DEM)}

Topographic maps collected on a scale of 1 50000. The number of sheets is nine maps, as shown in (Fig. 2). Contour lines and spot heights were digitized to produce a Digital Elevations Model (DEM). ArcSWAT (Soil Water Assessment Tool) was used to create a hydrological map showing drainage basins, valleys, and outlet points in the study area. It was used to simulate water at a catchments scale on a daily time step. It uses hydrologic response units (HRUs) that consist of specific land use, soil, and slope characteristics.

The whole methodology of the study is shown in the flow chart (Fig. 3). The inputs of ArcSWAT model are land use and land cover map, soil map, and The digital elevation model when the outputs are precipitation, evapotranspiration, and surface runoff.

\section{Results and discussion}

\subsection{Land cover map}

Land cover map of the study area was produced according to (FAO - LCCS) as shown in (Fig. 4). The total area and the identification of each land cover type shown in (Table 1). As shown from the map and the statistics, the domi- nant land cover is stony bare soil with a total area of $\left(1178 \mathrm{~km}^{2}\right)$. Vegetation cover in the study area belongs to two classes, rainfed herbaceous crops that cover $\left(154.1 \mathrm{~km}^{2}\right)$ and rainfed tree crops that cover almost $\left(195.8 \mathrm{~km}^{2}\right)$. Bare soil with fine sand covers $\left(531.7 \mathrm{~km}^{2}\right)$ while bare rock covers $(17.47$ $\left.\mathrm{km}^{2}\right)$. Urban settlements and road network did not exceed $\left(65.18 \mathrm{~km}^{2}\right)$.

An error matrix and Kappa Statistics were used on the classified map to determine the percentage of land cover accuracy. The overall accuracy of total classes for the entire the north-west coast was $87.47 \%$ as shown in Table (2). The selected sub-region in this study may have different accuracy if a separate sample is administrated for the sub-region only. Specifically, the accuracy of the separate built-up areas from vegetated lands is high, compared to finding boundaries amongst vegetation types. Also, the inclusion of GIS data layers into the final map the of north-west coast has forced the vegetation types into some mixed vegetation classes, which is not a typical land cover class able to be identified through spectral classifications only.

\subsection{Soil map}

Soil maps were produced depending on the Land Master Plane map. The study area was covered by one sheet of Land master plan, as shown in (Fig. 5) the different soil types with the total area of each soil type shown in the Table (3). The most common soil unit was (Very shallow gravelly and rocky soils and barren rock) that is coded as (R) with a total area of $\left(1701.4 \mathrm{~km}^{2}\right)$ followed by a unit (Rock with sandy loam on the slopes, undulating to rolling and rock) with a total area of $\left(229.51 \mathrm{~km}^{2}\right)$. The other soil types in the study area represented in small areas did not exceed $\left(80 \mathrm{~km}^{2}\right)$.

\subsection{Hydrological map}

The digital elevation model (10-meter resolution) produced, as shown in (Fig.6). From the digital elevation model, the drainage network was delineated and also the outlets that are expected to be the locations of the runoff rain for the study area, as shown in (Fig. 7). The watersheds and sub-basins also extracted, as shown in (Fig. 8). Accurate delineation of drainage networks is a prerequisite for many natural resource management issues (Liu and Zhang, 2010). As shown in the digital elevation model (DEM), elevation ranges from -3 meters below sea 


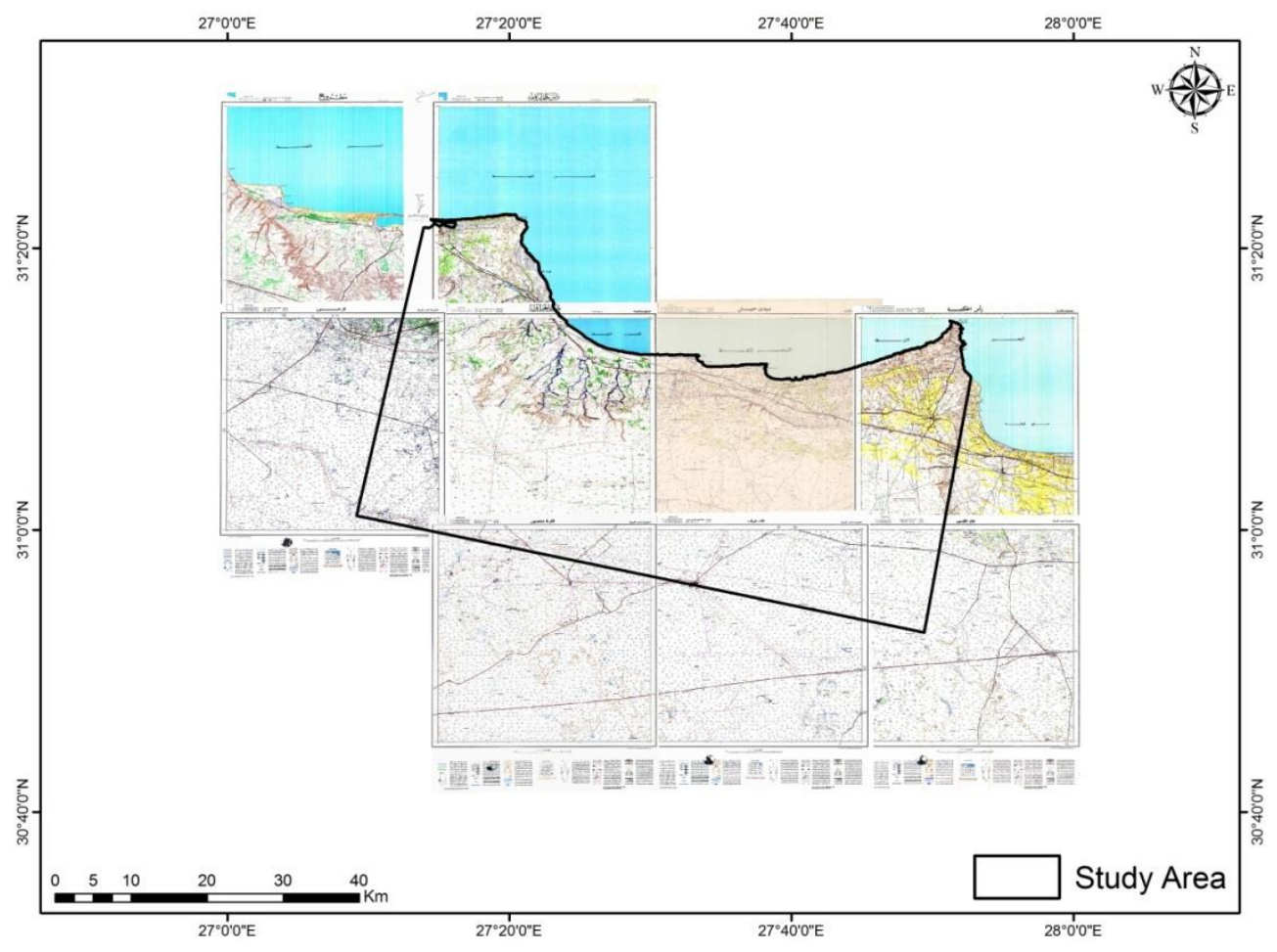

Fig. 2. Topographic maps of the study area

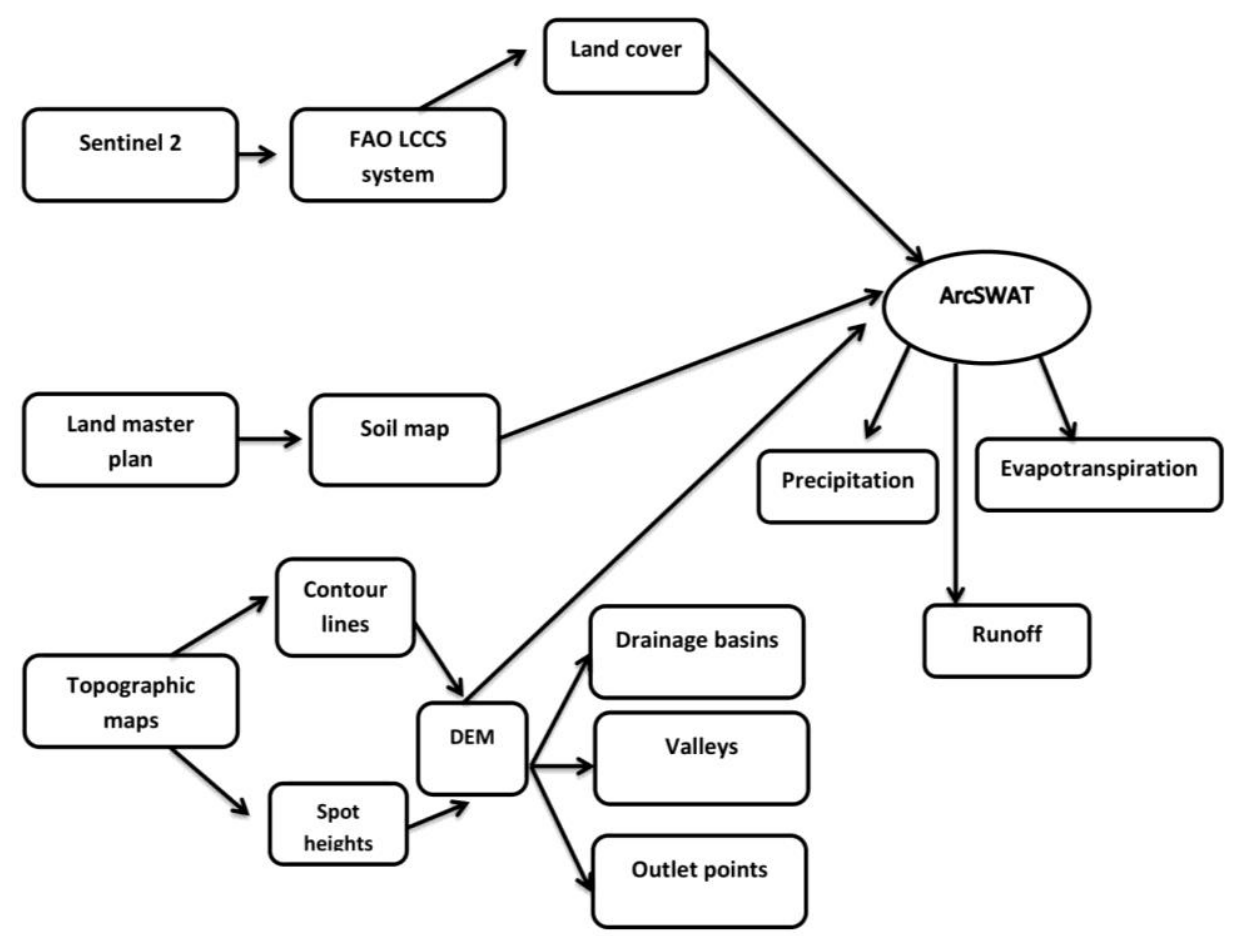

Fig. 3. Flowchart of the whole methodology 
Table 1. Land cover classes

\begin{tabular}{|c|c|c|}
\hline Land cover classes & $\begin{array}{c}\text { Land cover areas } \\
\left.\mathbf{( k m}^{2}\right)\end{array}$ & Description \\
\hline Rainfed herbaceous & 154.1 & Wheat and barley \\
crops & 195.8 & Fig and olive \\
Rainfed tree crops & 49.41 & Residential communities \\
Urban & 15.77 & Railways and mean road and secondary road \\
Roads & 1178 & Stony bare soil and other unconsolidated material \\
Stony soil & 17.47 & Bare rock \\
Bare rock & 13.39 & Very stony bare soil and other unconsolidated material \\
Very stony soil & 531.7 & Bare area \\
Bare area & \multicolumn{2}{|c}{}
\end{tabular}

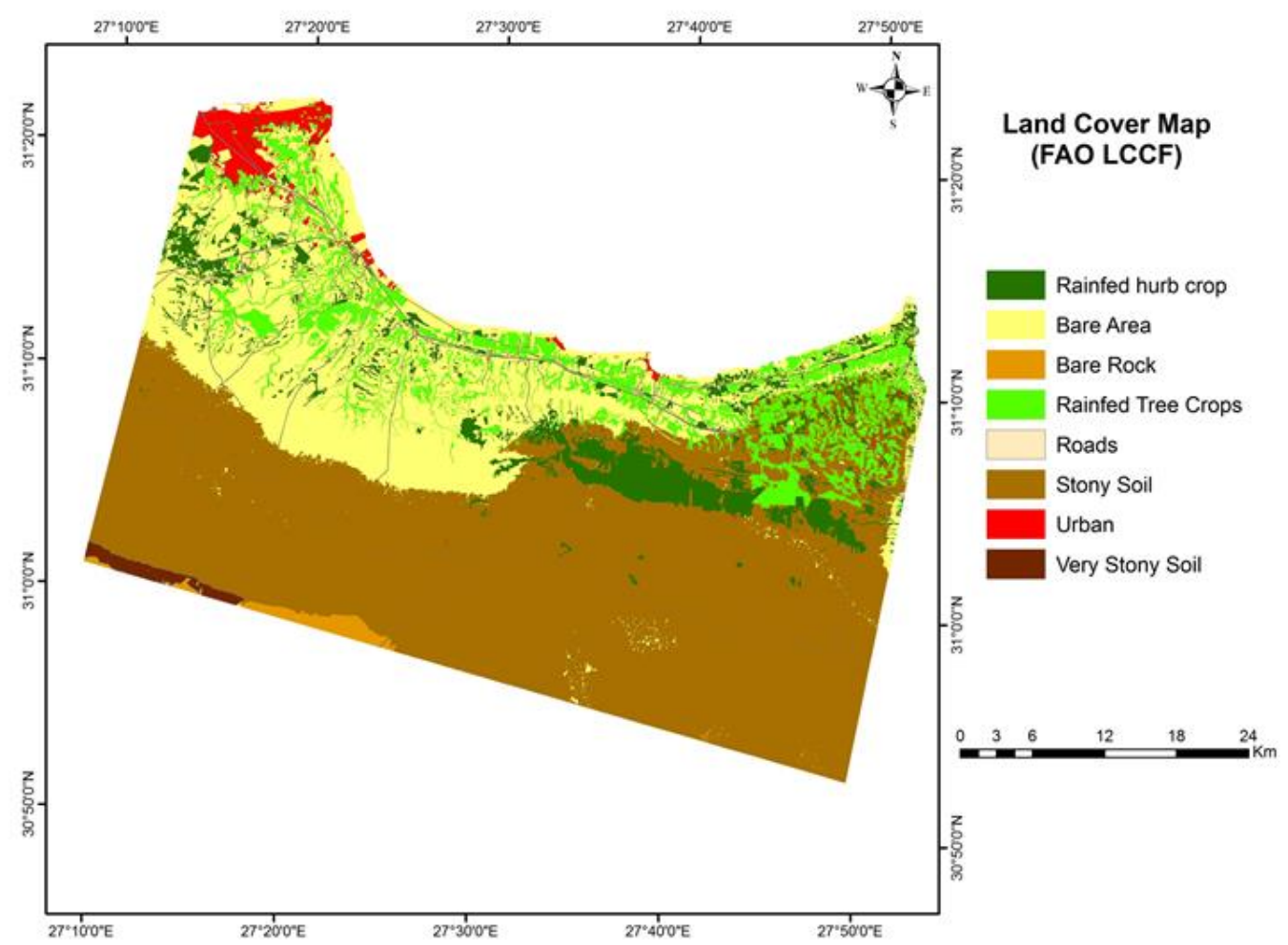

Fig. 4. Land use and land cover map for the studied area

Table. 2. Accuracy assessment of the north-west coast land cover classes

\begin{tabular}{|c|c|c|c|c|}
\hline Class Name & $\begin{array}{c}\text { Reference } \\
\text { Totals }\end{array}$ & $\begin{array}{c}\text { Classified } \\
\text { Totals }\end{array}$ & $\begin{array}{c}\text { Number } \\
\text { Correct }\end{array}$ & $\begin{array}{c}\text { Producers } \\
\text { Accuracy }\end{array}$ \\
\hline Rainfed herbaceous crops & 6 & 5 & 4 & $91.67 \%$ \\
Urban & 8 & 7 & 6 & $87.50 \%$ \\
Bare rock & 5 & 3 & 3 & $70.00 \%$ \\
Very stony soil & 6 & 6 & 6 & $91.67 \%$ \\
Stony soil & 5 & 5 & 5 & $90.91 \%$ \\
Bare area & 4 & 3 & 3 & $90.50 \%$ \\
Rainfed tree crops & 10 & 8 & 8 & $77.50 \%$ \\
Road & 3 & 3 & 3 & $100.00 \%$ \\
\hline Totals & $\mathbf{4 0}$ & $\mathbf{3 8}$ & $\mathbf{8 7 . 4 7 \%}$ \\
\hline \multicolumn{2}{|r|}{} \\
\hline
\end{tabular}



Egypt using remote sensing and geographic information system

Table 3. Different soil types in the study area

\begin{tabular}{|l|l|l|}
\hline Class code & Description & Area $\mathbf{~ k m}^{2}$ \\
\hline F3 & Eroded alluvial fans, exposed caliche & 29.64 \\
B1 & Deep sandy loam to clay loam soils & 36.05 \\
Do2 & Loose, sandy in dunes and sheets, locally consolidated and rock & 14.97 \\
R & Very shallow gravelly and rocky soils and barren rock & 1701.34 \\
Ds & Sheets, low and high dunes of quartz sand & 2.50 \\
F2 & Deep and moderately deep sandy loam or clay loam soils & 37.96 \\
Do1 & Lower coastal plains, dunes, and sheets & 2.61 \\
Wb & Deep sandy loam to loam with sand and gravel layers & 1.72 \\
Rd & Rock with sandy loam on the slopes, undulating to rolling and rock & 229.51 \\
F1 & Moderately deep to shallow sandy loam to clay loam soils & 79.63 \\
Pp & Saline soils of the lower wadis near the sea, stratified, wet & 9.86 \\
Bp & Poorly drained and very saline layered soil & 16.63 \\
\hline
\end{tabular}

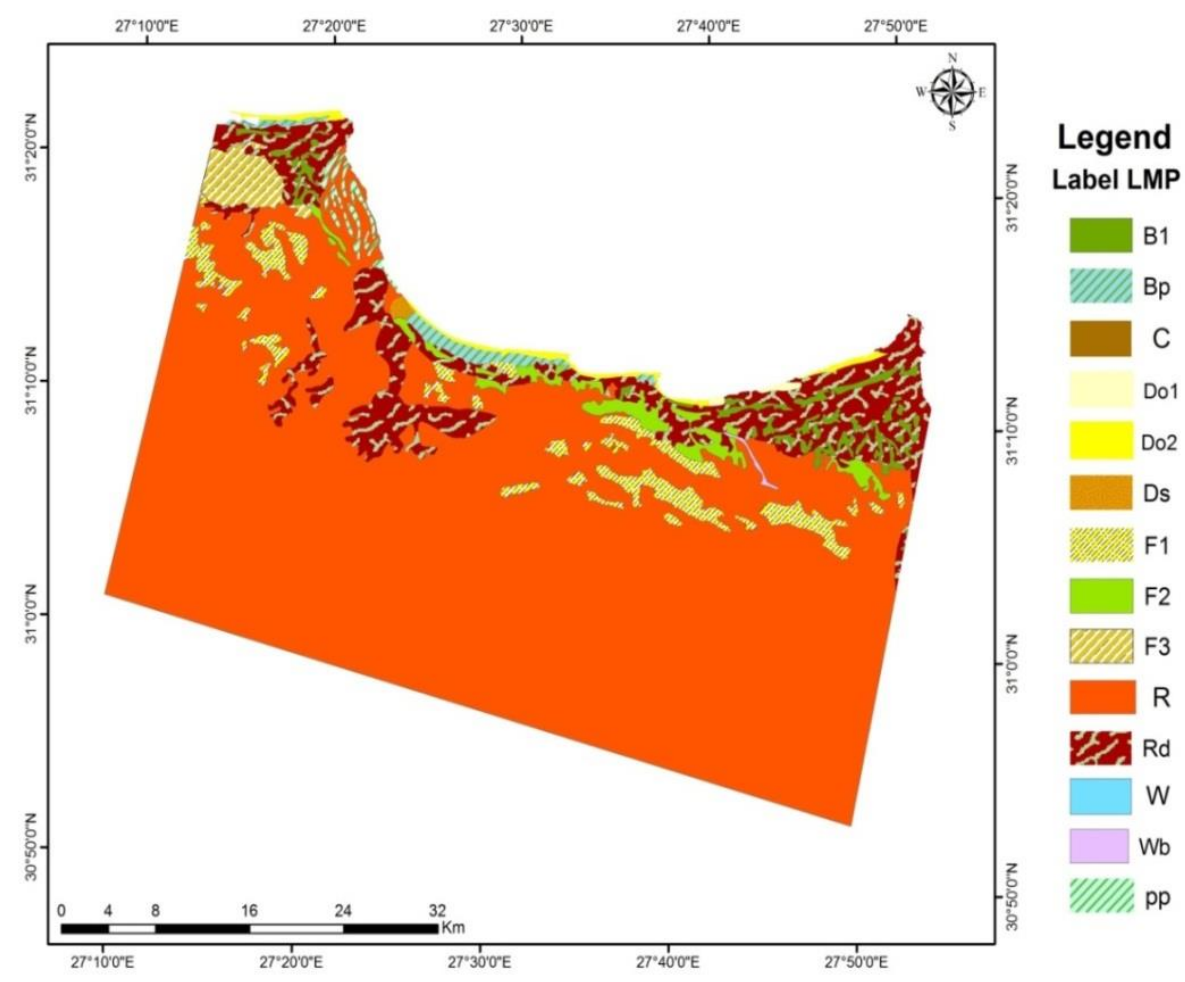

Fig. 5. Soil mapping for the studied area modified after land master plan (1986) 


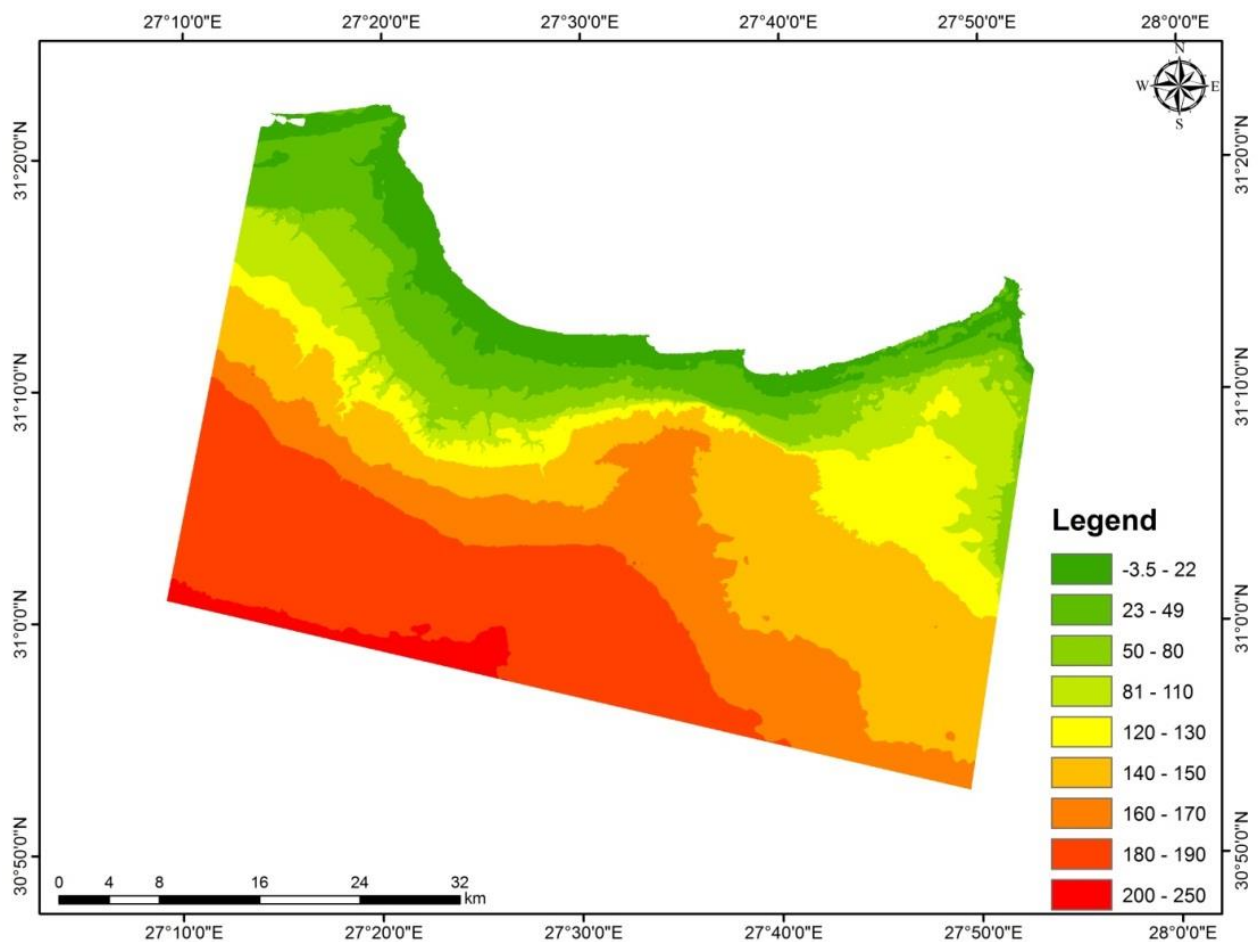

Fig. 6. Digital elevation model (DEM) of the study area

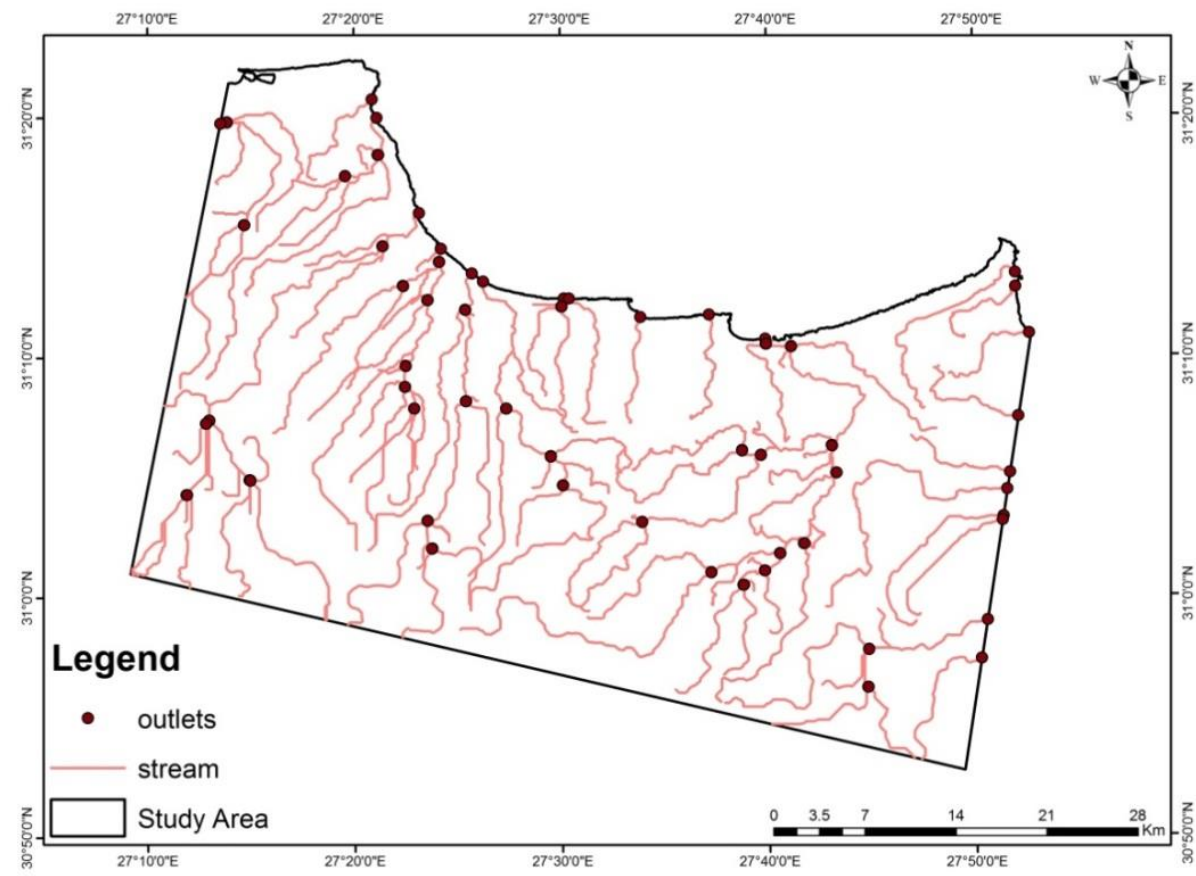

Fig. 7. Streams and rainwater catchment points 
Studying rain water catchment potentialities in the northwest coast of Egypt using remote sensing and geographic information system

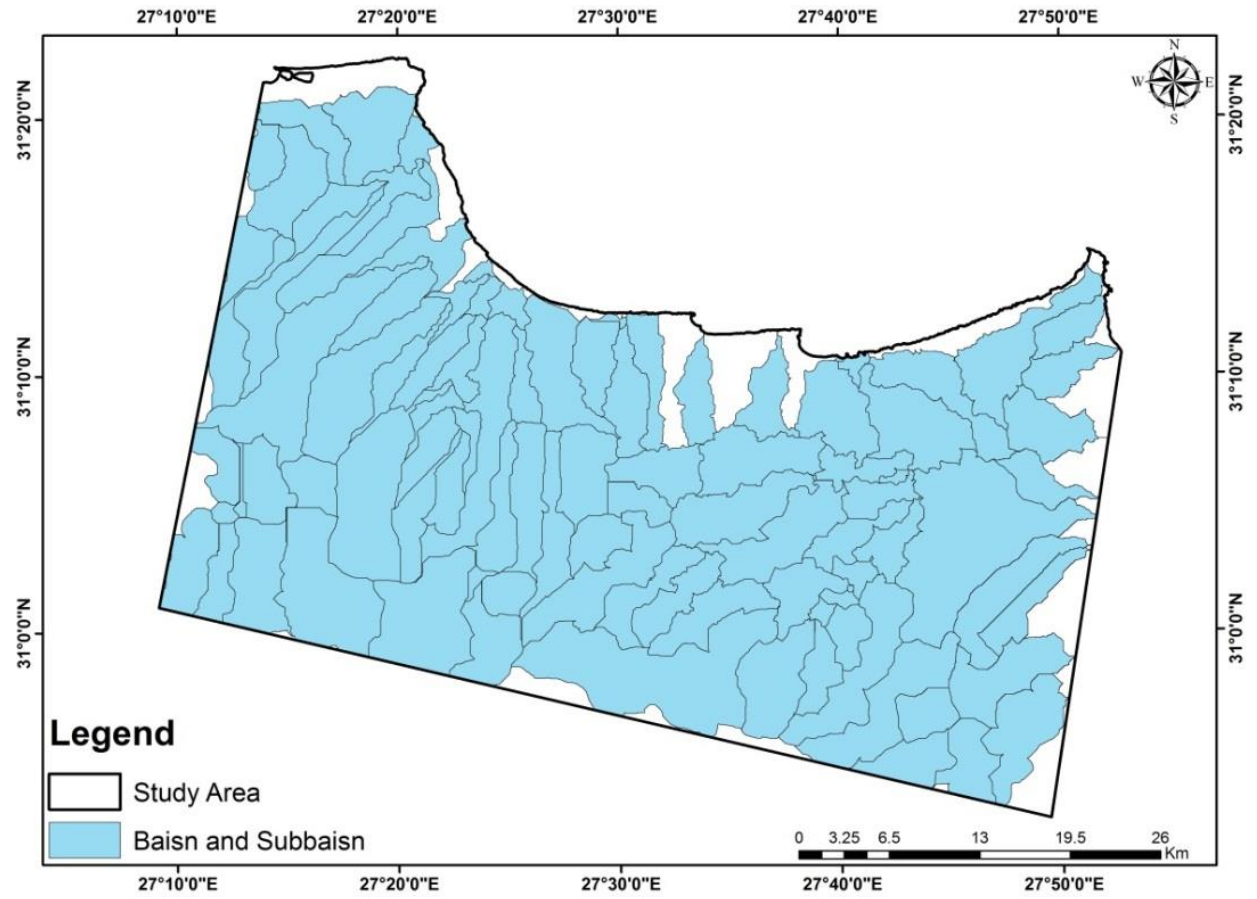

Fig. 8. Basins and sub-basins of the study area

level in the coastal line at the north of the study area to 250 meters above sea level at the most south of the study area. Coastal plain zone elevation ranged from 0 and $80 \mathrm{~m}$ when the southern plateau elevation ranged from 80 and $250 \mathrm{~m}$.

\subsection{ArcSWAT model}

Sustainable agricultural development investigated in this study through an assessment of water catchment potentialities on the northwest coast of Egypt through the optimal use of natural resources available in the study area such as rainwater for the purpose of sustainable agricultural development. Rainwater is the only source of irrigation in this area. However; a massive amount of water rain gets lost in each rainy season because of the insufficiency of water harvesting methods. The current study meets an urgent need to update information regarding the locations and amount of surface water. Rainfallrunoff models were simulated from 2004 to 2017 for 95 watersheds. The ArcSWAT model results for the investigated catchments shown in Table (4). As compatible with other findings from similar arid environments that showed minimal recharge contributions (Bazuhair \& Wood, 1996; Dettinger, 1989; Flint et al 2000 and Sultan et al 2011).
It was found that the application of the ArcSWAT model resulted from accurate data for actual evapotranspiration, surface water runoff quantity(SWR), precipitation and water yield across the period (2004 - 2017) as shown in the Table (4) and Table (5). Average annual precipitation was found higher than average annual actual evapotranspiration; this estimation proves the idea that the amount of precipitation is higher than the irrigation water requirement according to the current crop and vegetation cover. Therefore, there is a possibility to enlarge cultivated areas under specific conditions. These conditions are increasing water-storing capabilities either by small dams or by subsurface water stores. The locations of the barriers or water storages are the points of water catchment that were identified using ArcSWAT. Assessment of the monthly average surface water runoff showed that the maximum values are usually in December $(1.95 \mathrm{~mm})$, followed by January $(1.79 \mathrm{~mm})$ and February $(1.37$ $\mathrm{mm})$. At the same time, the maximum evapotranspiration registered in January (17.64 $\mathrm{mm})$ followed by February $(16.68 \mathrm{~mm})$ than December $(12.02 \mathrm{~mm})$. The maximum amount of rain in January $(20.79 \mathrm{~mm}$ ) followed by December $(19.05 \mathrm{~mm})$ than February $(16.55 \mathrm{~mm})$. The maximum water yield is in December $(2.05 \mathrm{~mm})$, followed by January $(1.91 \mathrm{~mm})$, then, February 
$(1.50 \mathrm{~mm})$. The same trend also found with surface water runoff quantity. Starting from February, the values of all factors descended gradually to reach almost zero in July and August when benefits begin to increase progressively starting from September.

The hydrological process was studied earlier in the northwest coast of Egypt and other arid areas in Egypt. However, it not explicitly explored in the current study area. Rainwater harvesting studied in the Fuka, Matruh area by (Rashash and El-Nahry, 2015) and in the Sinai peninsula by (Sultan., 2011) when chemical characteristics of groundwater in the Fuka basin were observed by (Yousif and Bubenzer, 2012).

Table 4. Average annual basin values

\begin{tabular}{|l|l|}
\hline $\begin{array}{l}\text { Average annual } \\
\text { precipitation }(\mathrm{mm})\end{array}$ & $81.9 \mathrm{~mm}$ \\
\hline $\begin{array}{l}\text { Average annual } \\
\text { surface runoff }(\mathrm{mm})\end{array}$ & $4.46 \mathrm{~mm}$ \\
\hline $\begin{array}{l}\text { Average annual } \\
\text { actual evapotranspiration }(\mathrm{mm})\end{array}$ & $70.5 \mathrm{~mm}$ \\
\hline $\begin{array}{l}\text { Average annual } \\
\text { water yield (mm) }\end{array}$ & $7.10 \mathrm{~mm}$ \\
\hline
\end{tabular}

Table 5. Average monthly basin values

\begin{tabular}{|l|l|l|l|l|}
\hline Month & $\begin{array}{c}\text { Rain } \\
(\mathbf{m m})\end{array}$ & $\begin{array}{c}\text { SWRQ } \\
(\mathbf{m m})\end{array}$ & $\begin{array}{c}\text { ET } \\
(\mathbf{m m})\end{array}$ & $\begin{array}{c}\text { Water } \\
\text { Yield }\end{array}$ \\
\hline January & 20.97 & 1.79 & 17.64 & 1.91 \\
February & 16.55 & 1.37 & 16.68 & 1.50 \\
March & 6.94 & 0.43 & 7.9 & 0.50 \\
April & 3.6 & 0.15 & 4.4 & 0.22 \\
May & 2.13 & 0.08 & 2.13 & 0.12 \\
June & 0.09 & 0 & 0.09 & 0.03 \\
July & 0 & 0 & 0 & 0.02 \\
August & 0 & 0 & 0 & 0.01 \\
September & 0.13 & 0 & 0.13 & 0.01 \\
October & 4.26 & 0.14 & 2.85 & 0.14 \\
November & 7.87 & 0.54 & 5.93 & 0.56 \\
December & 19.05 & 1.95 & 12.02 & 2.05 \\
\hline
\end{tabular}

\section{CONCLUSIONS}

The current study analyzed the hydrological characteristics for a case study on the northwest coast of Egypt. Vegetation cover has been sparse and inadequate for a long time resulted in insufficient agricultural production even for local communities in this area. Studying vegetation cover types using satellite imagery and assessed by field survey showed only inadequate winter crop cover mainly wheat and barley when tree cover is only fig and olive. This situation could be changed significantly when applying optimal water management methods.

Rain is the source of irrigation water; however, the amount of rainfall is very changeable across the years. This situation could be solved when maximizing the capabilities of water harvesting through building small dams or establishing subsurface water storages that were located accurately through using GIS and remote sensing. The digital elevation model produced from contour maps, and spot heights ranged from -3 meters below sea level to 250 meters above sea level showed gradual descending for elevation from the south towards the coastal line. Then, using the digital elevation model, the ArcSWAT tool was used to identify water catchment locations along the study area and analyze hydrological characteristics. After establishing water harvesting methods in these areas, they could be a starting for small agricultural communities with a significant amount of agricultural product and agricultural outcome.

\section{RECOMMENDATION}

Agricultural development in the study area could be achieved through the establishment of local small agricultural communities around the locations of water catchments. These new communities should depend on the new cropping pattern that could be added to the current ones under circumstances of optimal water harvesting methods. The new cropping pattern should guarantee maximum agricultural income through a drought, tolerant cropping pattern. Therefore, this work should be followed by simulative agricultural experiments to identify the new crops that could be cultivated successfully in this area.

\section{REFERENCE}

Ahlqvist 0. 2008. In search of classification that supports the dynamics of science: the FAO Land Cover Classification System and proposed modifications. Environment and Planning B: Planning and Design. 35(1), 169-186.

Arafat S.M., Saleh N.S., Aboelghar M. and Elshrkawy M. 2014. Mapping of North Sinai land cover according to FAO-LCCS. The Egyptian J. of Remote Sensing and Space Sci., 17(1), 29-39. 

Egypt using remote sensing and geographic information system

Bahnassy M. and Yehia H. 2007. Limitations and Implications for Egyptian Soil Spatial Data Infrastructure 6(3), 34-50.

Bazuhair A.S. and Wood W.W. 1996. Chloride mass-balance method for estimating groundwater recharge in arid areas: examples from western Saudi Arabia. J. of Hydrology 186(1-4), 153-159.

Borah D.K. and Bera M. 2004. Watershed-scale hydrologic and nonpoint-source pollution models: Review of applications. Transactions of the ASAE. 47(3), 789-803.

Dettinger M.D. 1989. Reconnaissance estimates of natural recharge to desert basins in Nevada, U. S. A., by using chloride-balance calculations. J. of Hydrology (Amsterdam). 106(1), 55-78.

FAO, 1965. Protein requirements. Nutrition meetings report series No. 37. Food and Agriculture Organization of the United Nations, Rome. 71 p.

Flint A.L., Flint L.E., Hevesi J.A., DAgnese F. and Faunt C. 2000. Estimation of regional recharge and travel time through the unsaturated zone in arid climates. Dynamics of Fluids in Fractured Rock 122, 115-128.

Liu X. and Zhang Z. 2011. Drainage network extraction using LiDAR-derived DEM in Volcanic Plains Area 43(1), 42-52.
Nian Y., Li X., Zhou J. and Hu X. 2014. Impact of land-use change on water resource allocation in the middle reaches of the Heihe River Basin in northwestern China. J. of Arid Land 6(3), 273-286.

Ramanarayanan T., Narasimhan B. and Srinivasan R. 2005. Characterization of fate and transport of isoxaflutole a soil-applied corn herbicide in surface water using a watershed model. J. of Agric. and Food Chem. 53(22), 8848-8858.

Rashash A. and El-Nahry A. 2015. Rainwater harvesting using GIS and RS for agriculture development in the Northern Western Coast, Egypt. J. Geogr Nat Disast. 5(141), 21670587.

Santhi C., Arnold J.G., Williams J.R., DugasW.A., Srinivasan R. and Hauck L.M. 2001. Validation of the swat model on a large RWER basin with point and nonpoint sources 1. JAWRA J. of the American Water Resources Association 37(5), 1169-1188.

Sultan M., Metwally S., Milewski A., Becker D., Ahmed M., Sauck W. and Wagdy A. 2011. Modern recharge to fossil aquifers: Geochemical, geophysical, and modeling constraints. J. of Hydrology 403(1-2), 14-24.

Yousif M. and Bubenzer 0. 2012. Perched groundwater at the northwestern coast of Egypt: a case study of the Fuka Basin. Applied Water Sci., 2(1), 15-28. 


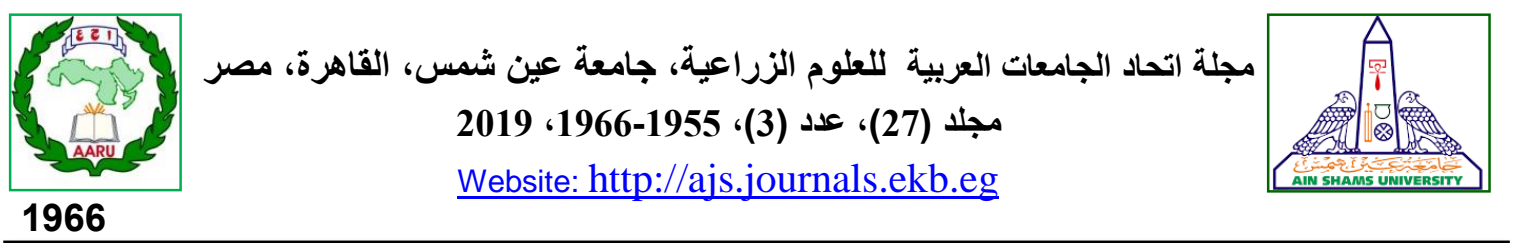

دراسة إمكانيات مستجمعات المياة فى دراسة حالة فى الساحل الثمالي الغربي لمصر

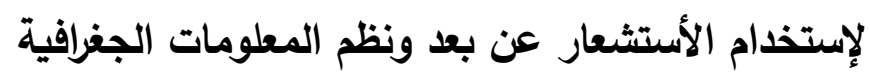

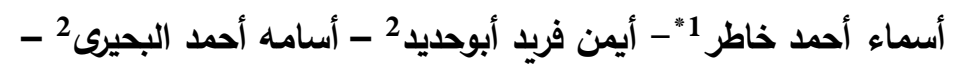

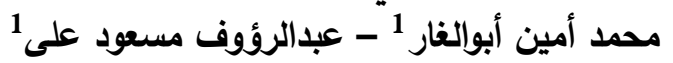

[157]

1- شعبة التطبيقات الزراعية والتربة وعلوم البحار - قسم التطبيقات الزراعية - الهيئة القومية للأستشعار عن بعد وعلوم

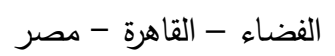

2- قسم البساتين - كلية الزراعة - جامعة عين شمس - ص.ب - 68- حدائق شبرا 11241 - القاهرة - مصر

*Corresponding author: asmaaahmed khater@yahoo.com

Received 7 July, 2019

Accepted 25 September, 2019

والصخرية والصخور القاحلة). تم تجميع البيانات المناخية من المعمل المركزى للمناخ. أظهرت المنية النتائج

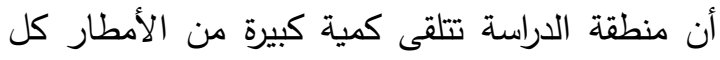

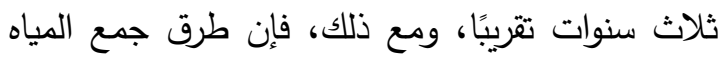

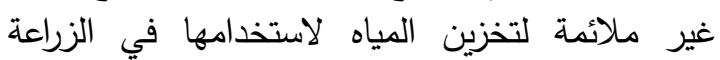
خلال مواسم الجفاف. كمية الأمطار (81.9 مد)،

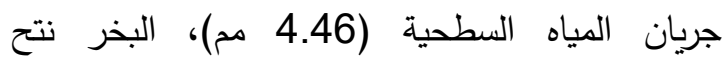
المحتمل (70.5 مم)، والبخر نتح الفعلى (2004 (2017 (2010 مم)

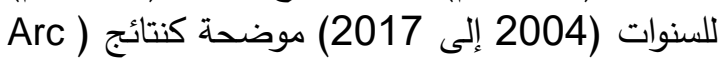

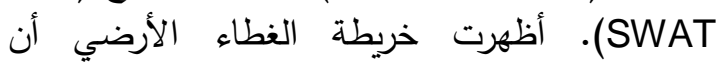
محاصيل الأشجار (الزيتون والتين) تغطي 195.8

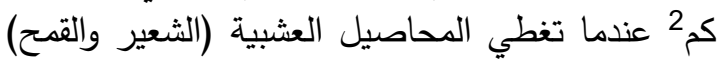

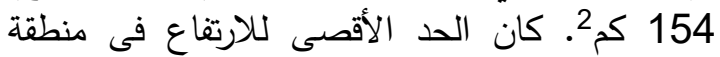

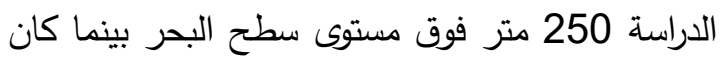
أقل ارتفاع -3 متر تحت مستوى سطح البحر ـ تستقبل

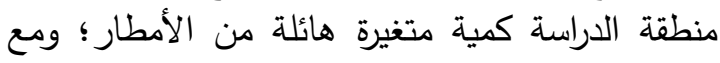
ذلك، فإن طرق حصاد المياه غير مناسبة لتخزين المياه

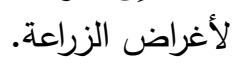

الكلمات الدالة: 2entinel-2، آداة تقييم التربة والمياة،

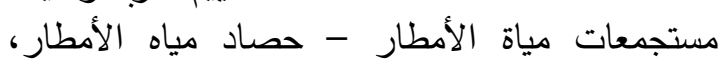

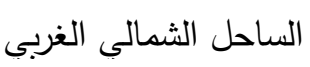

\section{الموجـــــــز}

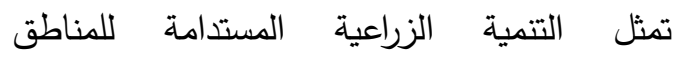

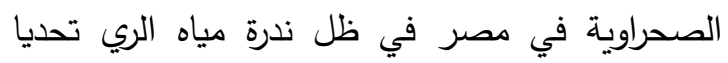
وطنيا كبيرا. لا تضمن تقنيات حصد المياه الحالية على فلى لفياه

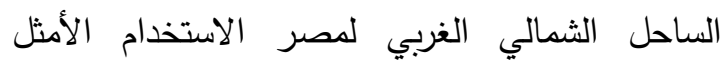

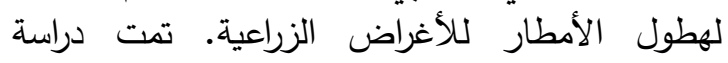

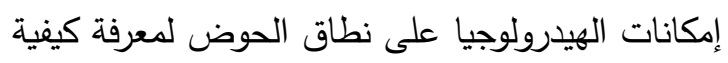

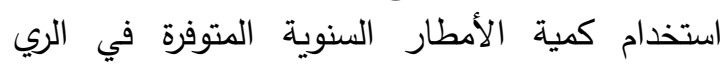

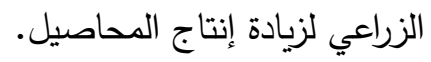
تتضمن هذه الدراسة بيانات متعلقة بالإنتاج الزراعي الزيات في شكل طبقات جغرافية مكانية بما في ذلك الكان المناخ الزبان

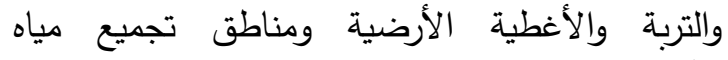
Sentinal-2 الأمطار. تم إجراء التصنيف الأرضية لصناء

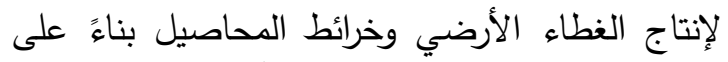
نظام (FAO) لتصنيف الغطاء الأرضي. تم استخدام خطوط الكنتور ونقاط ارتفاع لإنشاء نموذج الإتيف الأنفاع الرقمي (DEM). بعد ذلك ، تم استخدام DEM لتحون التحديد

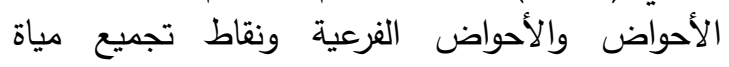

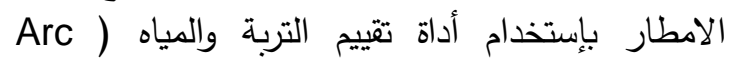

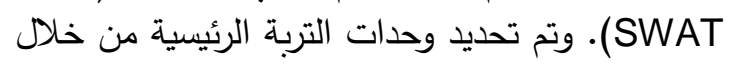

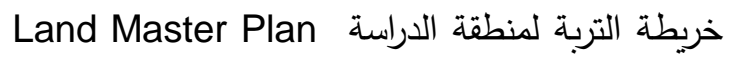
وكانت الوحدات الاكثر انتشارا هى (التربة الضحلة جدا 



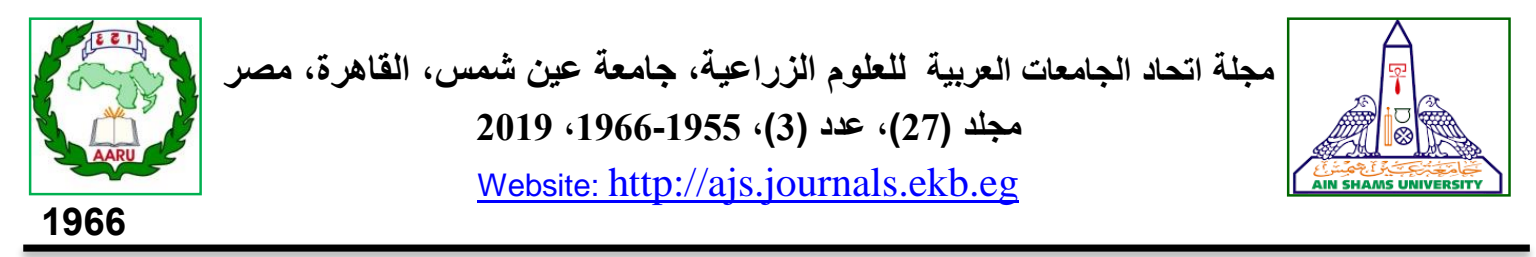

